\title{
PARTICIPATION IN DEVELOPMENT: LEARNING FROM THE PAST AND PRESENT IN THE REPUBLIC OF KOREA
}

\author{
Yunjeong Yang*
}

The present study draws on two case studies, one on village dynamics during the 1970s rural community development movement in the Republic of Korea and the other on present day challenges and learning based on the experiences of a non-governmental organization from the Republic of Korea in implementing a community project together with local villagers in Cambodia. The study argues that the participatory approach, despite recent criticism and challenges associated with it, should remain the core mode of development cooperation because of its intrinsic and instrumental values in efforts to develop a sustainable community. Local leaders' accountability and leadership, as well as genuine partnerships, involving equitable sharing of power in decisionmaking among various stakeholders, including external donor agencies, are also underlined as crucial in engaging local people in their own development initiatives.

\footnotetext{
Associate Professor, Department of International Development Studies, Graduate School of International and Area Studies, Hankuk University of Foreign Studies, Seoul (e-mail: yunyang@hufs.ac.kr). I thank all of the participants of the case studies for their sincere and honest sharing of their experiences, without which this work would not have been possible. The full versions of the two case studies presented here were published in early 2016 in two other academic journals, for which copyright to reuse in part was duly sought and gratefully granted. An earlier draft of this paper was presented at the second North-East Asia Development Cooperation Forum (NEADCF) in Tokyo on 31 October and 1 November 2015, which I attended with generous support from the Korea Association of International Development and Cooperation (KAIDEC) as chair of their International Cooperation Committee. An earlier draft of this paper benefited from helpful comments of Professor Lee Heejin. I am also grateful to the APDJ editorial board for its comments as well as its encouragement to publish this paper as part of the outcome of the Second NEADCF. Finally, this work was supported by a research fund from Hankuk University of Foreign Studies. A summarized version of this paper was first published in the Proceedings of the sixth International Conference, organized by the Consortium for Asian and African Studies (CAAS), which was held on 27 and 28 October 2015.
} 
JEL classification: $\mathrm{O} 20$.

Keywords: Participatory approach, community development, development cooperation, partnership, Republic of Korea.

\section{INTRODUCTION}

"Sustainability" is now the key word in development. The Sustainable Development Goals have become the new global development discourse and will certainly be the core source of guidance for future development cooperation practices. Sustainability often has an environmental sense, but it should also encompass the social governance of development practices. Sustainability set the tone for the way of thinking and acting in development cooperation or partnerships. In the present paper, sustainability is addressed as an issue of governance and referred to with regard to the participatory approach. This is because, despite recent criticism of the participatory approach as being a "tyranny", and the often debated challenges tied to (Cooke and Kothari, 2001; Cornwall and Brock, 2005; Mansuri and Rao, 2012; Rahman, 1995), the author is of the view that only truly genuine participation by the local population can render any development initiatives that are sustainable in the longer term (see also Hickey and Mohan, 2004; Lyons, Smuts and Stephens, 2001). Participatory governance is also included as part of the strategic means towards achieving the Sustainable Development Goals. Under Goal 16, the importance of "build[ing] effective, accountable and inclusive institutions" is underlined. Global partnerships among diverse stakeholders, including public, private and civil society, which is referred to in Goal 17 as strengthening the means of implementation for sustainable development, is the ultimate concern of this paper, which aims to suggest a key approach for its successful achievement, namely, community participation.

That said, the objective of this paper is to share examples from development (and cooperation) experiences involving the Republic of Korea, drawing on two case studies. The first study (case study I) is centred on earlier rural modernization experiences of the Republic of Korea, which occurred during the 1970s. By contrasting two villages' within-village governance styles, the importance of a community-driven development approach in transforming an underdeveloped village to a modern village in a sustainable manner is stressed. The second study (case study II) draws on current development cooperation practices of the Republic of Korea, with an example of a non-governmental organization (NGO) from the Republic of Korea working with a village in Cambodia, and demonstrates the challenges experienced in getting the villagers to participate in the process. Both case studies are based on a triangular methodology involving document and archive (for case study I) analysis and the author's field visits to conduct interviews with key persons concerned 
during 2014-2015. ${ }^{1}$ The current study, being a synthesis of the two case studies, by learning from both past and the present, is expected to reaffirm the value of and need for a participatory approach for sustainability.

Before the two case studies are presented, existing literature on participatory development is reviewed in the next section. Sections III and IV contain presentations of the two case studies, respectively, to be followed by the synthesis of the main findings and the conclusion.

\section{PARTICIPATION AND POWER}

Participation, perceived as having an intrinsic and instrumental value, is now commonly understood as an essential component in any development process - at least in the Western development discourse (Bhatnagar and Williams, 1992; Chambers, 2005; Cornwall, 2011; Hickey and Mohan, 2004; Mansuri and Rao, 2004; 2012; Mohan and Stokke, 2000; VeneKlasen and Miller, 2002). The essence of a participatory approach is to recognize that people whose lives are to be changed by development interventions should have a say in what these changes are to be, and how they will take place. A simple presence in a village development committee (VDC) and serving as a rubber stamp, for instance, would not change existing power dynamics within and outside the community, and risks engagement being "tokenistic" rather than involving genuine "participation".

Diverse views and forms of participation are reflected in different definitions and "ladders" of participation" (such as Arnstein, 1969; Bhatnagar and Williams, 1992; Choguill, 1996; VeneKlasen and Miller, 2002; Wilcox, 1994). Although ladders are often useful when seeking to put participation into practice, Chambers (2005, p. 105) warns of the risk because "higher on a ladder (that is, being more participatory) is not

Key informants for the case study I include former and incumbent Rijangs (village chiefs) and some key village development committee (VDC) members of the 1970s in the two respective villages (see appendix I). Questions addressed include those relating to selection processes of village leaders and VDC members, decision-making processes and participatory aspects, and subjective assessment of the Saemaul Undong. Interviews for case study II involved the representative of the concerned Siem Reap office of the NGO concerned and general managers of both the Seoul and Siem Reap offices. In-depth qualitative interviews were generally open-ended with regard to meanings and challenges of participation by local villagers in their two projects under examination (see appendix II). The full description of the methods as well as detailed analyses of the two case studies presented here as extracts are available in recent publications by the author (see Yang, 2016 a; 2016 b).

2 Participation has types and degrees, often expressed as ladders, such as information-sharing $\rightarrow$ consultation $\rightarrow$ decision-making $\rightarrow$ initiating action (Bhatnagar and Williams (1992) suggested this description for the World Bank, as cited in Chambers (2005, p. 104)). 
necessarily better"; while "equity is important (who gains and who loses)" - as much as, or perhaps even more than, simply how many participate.

Meanwhile, the development studies literature has often separated leaders or elites on the one hand (emphasizing their roles and impacts on a society and its development), and (mostly) poor and vulnerable people on the other hand (underlining the importance of engaging the poor and vulnerable in the development process). The key issues and challenges discussed in the literature on elites are to avoid "elite capture" by "greedy" elites and instead, to engage "benevolent" elites and fully exploit their social capital (Dasgupta and Beard, 2007; Fritzen, 2007; Platteau, 2004; Platteau and Abraham, 2002; Wong, 2012). The engagement of non-elites (ordinary people in general), and of the poor and vulnerable, in particular, in the development process is what is referred to as the "participatory approach". Community empowerment is often considered a "counter-elite" approach (Dasgupta and Beard, 2007), and elites and other (poor) people's power relations are, as such, often juxtaposed as constituting a zero-sum game.

People's participation and elites' roles, however, are not necessarily two separate things. It is often forgotten that the importance of different stakeholders at different stages of development may differ. As Chambers (2005, p. 95) underlines, major tasks and policies in the first stage of development should be "finding and using leaders who will help to get development moving"; Chambers also states that "leaders are still important" even in later stages, during which ordinary people are to participate genuinely in their development processes. Elites, usually being "a distinct group in a society which enjoys privileged status and exercises decisive control over the organization of society", have the power to allocate and create resources, to exert political influence and to design institutions. In turn, they can either "promote participation and information flow, or ...simply cement the position of a particular group within the governance structure" (DiCaprio, 2012, pp. 5-6; see also Amsden and DiCaprio, 2012). In that sense, it can be argued that participatory development requires and depends on a certain nature of leadership and governance, and that this is a matter of "power" and "equity" (see also Gaventa, 2006).

Power, which is an issue within a community, can also be an issue among stakeholders, including, for example, external donor agencies. Participation has become a "tyranny" (Cooke and Kothari, 2001), often imposed as "an act of faith" (Cleaver, 2001, p. 36), mostly by white interventionists. However, the superior attitudes of Asian donors are not necessarily very different. When participation becomes an "external concern" (Mosse, 2001), the potential of development in terms of long-term sustainability is easily lost. This is why power and agency remain such pervasive themes (Cornwall, 2004; Gaventa, 2004; Hildyard and others, 2001; Kelly, 
2004; Kothari, 2001; Williams, 2004). Having noted this, the main subject of observation and examination of the case studies presented here is the nature of participation, as well as that of local leadership (case study I) and external intervention (case study II), both of which must play an important role in determining the nature of participation by their power relations with the local community concerned.

\section{CASE STUDY I: TWO “SELF-RELIANT" VILLAGES DURING THE RURAL MODERNIZATION MOVEMENT SAEMAUL UNDONG IN THE REPUBLIC OF KOREA IN THE $1970 s^{3}$}

Saemaul Undong ${ }^{4}$ was a nationwide campaign for rural modernization that was implemented in the Republic of Korea during the 1970s. It was originally designed to make rural villages more cooperative, more productive and more modern. Having been initiated by the late President Park Chung Hee, Saemaul Undong is often defined as a "planned, government-led, and top-down movement for social change" (Kim, 1981, p. 2; see also MOHA, 1980; Park, 1974; Park, 1998; Whang, 1981). With a strong will and leadership from the very top of the administration, the Government offered extensive interministerial and top-down support to the local government, including technical and local leadership training. The Government categorized villages into three categories, namely, basic, self-help, and self-reliant, according to a set criteria. More recent research finds that local leaders (then called Saemaul Leaders, officially acknowledged by the Government) deserve credit for successfully obtaining their fellow villagers' participation in the campaign (Han, 2010; Kim, 2009; Lee, 2013; Yang, 2015; Yoon, 2011). However, issues regarding the massive number of people who participated, and the nature and purpose of that participation - and consequently, its sustainability - remain subject to debate (see, for example, Han, 2004; Hwang, 2006; Hwang, 2011; Moore, 1985).

When asked how the Saemaul Undong was understood, most of the then local participant-interviewees mentioned villagers' free labour and mobilization for most so-called Saemaul projects, which were mainly of three types: (a) changing individual household living spaces, including roofs, walls, kitchens, and toilets, into more

This section is derived in part from an article published in Community Development Journal, published online: 11 July 2016, doi:10.1093/cdj/bsw023 (copyright Oxford University Press) (see Yang, 2016b).

4 Saemaul Undong can be literally translated as "new village movement". 
modern styles; (b) improving village infrastructure, such as roads, farm feeder roads, bridges and village halls; and (c) conducting various income-earning activities, including collecting grass and weeds and turning them into humus to be used to increase the output of agricultural products (mainly rice). Nevertheless, this does not mean that every village responded proactively to this Government "call" to modernize the rural area, or that, as a consequence, Saemaul Undong succeeded to upgrade its quality of living in a sustainable manner. A new and surprising finding from the present study is that self-assessment among participants of a village officially classified as "successful", which was promoted as one of the "model Saemaul villages", suggests that participants are in fact very negative about the long-term impact of Saemaul Undong (particularly in terms of income-earning projects).

This study suggests that a true measure of success is more closely related to the nature of local governance, rather than Saemaul Undong per se. In the next section, this is explained by discussing the local leadership accountability and the nature of participation explored as key success factors. The focus was on two villages, which were selected among the "best performers" because: they were categorized as self-reliant; reasonable data about them were available from the database; and their locations were convenient for fieldwork (see appendix I for the summary of the case study villages and interviewees).

\section{Accountable local leadership, power changes and participatory governance}

Leaders of the two villages are recorded as having held the leadership position for at least 16 years. The main difference between the two, however, is that Village A's leader Kim, reported himself to be the Saemaul Leader and remained in that position throughout the period, while Village B's leader Jeon, was elected by villagers at a village congress and served for a certain fixed period several times. According to Jeon, this was "mainly because no one else volunteered to come forward to work as leader" (in between those terms when he did not serve, a few other persons served for short terms). In summary, Village A was under the "quasi-dictatorial" leadership of Kim while Village B was run in a democratic way.

This difference between the two villages was related to the root governance style of the villages concerned: the leader of Village A, Kim, was the son of a Rijang of an older generation, and was discharged from the army as a disabled veteran in the era in which military personnel were in charge of the government (the Park Chung Hee regime). His family had close connections with the then high-ranking officials and benefited from substantial support from the government throughout the 1970s (revealed during an interview with Jeong). Once appointed as Saemaul Leader of a "showcase village", Mr. Kim selected key figures to work with him under his 
leadership throughout the 1970s. Both interviewees, Kim(a) and Jeong, were persuaded to work for the village by leader Kim.

Jeong acknowledges that due to the leadership of Kim, the village has seen notable changes and life has become much more convenient. Nonetheless, when asked about the order of the names on a memorial stone erected in 1983 in front of the village hall in commemoration of contributors to the Saemaul Undong of the 1970s, Jeong firmly stated: "I don't want to comment on that. You will understand why [as you heard of the inter-clan conflicts]." Apparently, Jeong was not happy to see his name written beneath that of the two Kims, the powerful clans in the village over a number of generations. It transpires that the Saemaul Leader of Village A and the key leadership, comprising four other persons, held the key positions within VDC throughout the 1970s, if not the entire period for which data were available. In summary, in Village A, a limited number of persons, mainly selected by the former Saemaul Leader Kim, held the position for more than a decade. At the same time, existing power relations appear to have been maintained until very recently. In other words, truly transformative power changes did not occur in Village A.

In contrast, Village B's leader Jeon was the very first village chief elected by vote at the village congress - at the time of the election, he was serving as the first assistant chief of the village's five subregions, supporting the Rijang.

I was young [late 20s] and no one was behind me [as a sponsor or so]. Sincerity was all I had. I've never been in arguments with anyone in the village. Maybe that's why they've come to listen and support me at last. ...As you see, most of the VDC members were about my father's age. Under them, I served as a leader. (Interview with Jeon, emphasis added)

Interestingly, Jeon used the words "under" rather than "with", which may show his humble character, but it certainly demonstrates that he was not in a dictatorial position similar to that of leader Kim in Village A. Jeon, a son of an immigrant family from another village, began serving as the first assistant chief in the late 1960s, and after four years he became the very first Rijang to be elected by fellow villagers, in the village congress in 1972. Jeon said that he found that the only explanation for his victory was his sincerity, which led to his being assessed as an "appropriate serviceman for the village". The term "serviceman", rather than "leader", for the leadership position, which was used both by the leader himself and also by his fellow villagers, was definitely different from what was discovered in Village $A$, where the Leader was literally the head and director, and had noticeable power. 
In summary, the nature of leadership and its accountability differed between the two villages: Village $B$ had proper competition and an election to elect a representative of the village democratically; VDC members were representatives who were elected based on recommendations among villager-residents living in respective subregions; and the village congress was an arena from which any decisions made based on discussions among these VDC members, along with a Rijang and a Saemaul Leader, would be approved formally. In contrast, Village A had a strong Saemaul Leader who mostly selected his VDC members and initiated most projects, with village congresses mainly serving as a stamp of approval to implement those projects.

Indeed, various income-earning projects were implemented in Village A, including pork and cattle farming, nurseries of various fruit trees, and ginseng production, most of which were possible through several grants that the village received for being an "exemplary" or "success model" village - a status for which it was nominated almost every year at the National Saemaul Congress. According to the archival data, Village A was a "success". The villagers' assessment, however, was not as generous as the view suggested by the archival records:

None of them [Saemaul projects] in fact can be called a success. (Interview with Kim, b)

Villagers did tremendous work, indeed, but it was not popular, to be honest. We did various projects. Lots of them... [However] we didn't earn much income out of them, but we only had performances. (Interview with Cho, emphasis added)

The last sentence quoted above sounds paradoxical but the apparent paradox can be explained by reference to the (non-)participatory approach: the real performance of earning projects was considered less important than the transformation of the village's appearance into that of a model village. This transformation involved changing the living environment, for example, by modernizing roofs, kitchens and infrastructure, such as roads and bridges. This was the first stage of Saemaul Undong. While admitting the importance of this kind of transformation for improving living standards, its limitation as a means of sustainable rural development should nevertheless be acknowledged. When these things happen in a top-down manner, the impact can be even less long-lived. The interviewees of Village A acknowledged that the public officials did not show any particular interest in seriously verifying the actual performance of their publicly financed projects, as in the villagers' words, "they knew that the projects would fail. How on earth can we expect any good results, coming to see just with a few months' notice?" The village was going to get 
the funding anyway and the impact of the projects did not last for long, as the villagers admitted.

In contrast, people in Village B were confident of having achieved the self-made target of a "high-income-earning village", a slogan coined in the early 1970s. Until today, Village B is known for its good-quality greenhouse lettuce. One particularity associated with Village B is the villagers' explicitly distinctive description of their success resulting from "a grassroots movement for rural community development", rather than from the government-led, top-down campaign, Saemaul Undong.

I was just one step ahead in the rural community development movement, rather than Saemaul Undong [smiles]. (What's the difference?) Saemaul Undong was led by the government while rural community development was something that we, a few village people with leadership, initiated voluntarily, without asking for power on the side of government. That could be the core difference. ...We began by a village credit union, purely community-driven. (Interview with Min, Village $B$, emphasis in original)

Both interviewees from Village B mentioned the contribution made by a then young (late 20s) missionary who served in the village for ten years from 1959 onwards in emphasizing the importance of saving, which eventually led to the village's credit union. This missionary also helped the villagers to learn how to grow greenhouse lettuce through a Christian institution for educating rural people, and, in turn, how to produce products during off-farming seasons. This eventually led to the coining of the village's slogan. Although Saemaul Undong started a few years later and villagers were, therefore, able to benefit from public support, in the form of loans at low rates of interest, under the name of income-earning Saemaul projects, both activities, in fact, had been initiated by the village. Min, one of the interviewees from the village and founding president of the village's credit union, while acknowledging the missionary's devotion and contribution, emphasized that "who in fact organized and implemented the actual activities was us [village people]."

In summary, Saemaul Undong, literally translated as "new village development", as assessed strictly from the example of Village B, was not a national initiative established by the top, but rather a drive that started from and depended on a few villages' exemplary initiatives, beginning in the 1960s, to make their villages a better living place. Additionally, in Village B the power conflict among clans was not particularly noticeable, in contrast to Village A. This partly contributed to making power changes possible, as Jeon, the son of an immigrant family and less wealthy and less educated than the other candidate, was able to become Rijang and served 
the village in that position for many years. In summary, this genuine grassroots community development was transformative and served as the true engine of the village's long-term success. ${ }^{5}$

\section{CASE STUDY II: LOTUSWORLD, A NON-GOVERNMENTAL ORGANIZATION FROM THE REPUBLIC OF KOREA AS A PARTNER IN CAMBODIA IN THE 2010s 6}

The second case study is drawn from recent experiences of LotusWorld (hereafter LW), a development NGO from the Republic of Korea specializing in childcare and education that has worked in Siem Reap, Cambodia since 2006. The study is mainly about continuity and changes between the two recent LW projects (summarized in appendix II) although the reflections from the interviews conducted go beyond these two particular projects. One project is an education project in Puok district, which was implemented in 2012, covering two villages and the neighbouring area of the LW centre (Project A) and the other one is the Phnom Krom village development project, which has been ongoing since 2013 (Project B). During October 2014, the author visited the LW Siem Reap office, as well as the village that LW has been working with since 2013, and conducted interviews with the head and representative of the LW Siem Reap Childcare and Education Center, the general manager of the Siem Reap office, the manager and volunteer from the Republic of Korea at the village site, and a focus group made up of VDC members. The author also visited and interviewed the general manager of the LW head office in Seoul before doing the fieldwork.

At the beginning of each interview, both the general managers in Seoul and in the Siem Reap offices quickly acknowledged that Project A was a failure, not only regarding its own set goals, but particularly in terms of the participatory approach. The project started without solid pre-planning, let alone a rigourous assessment of the village's needs, partly because the project was decided by a top-down approach, but

\footnotetext{
5 Unlike Village A, where old farmers (including interviewees and Saemaul participants) live mainly on subsistence farming (from Rijang Cho's account), the majority of villagers in Village B were still engaged in the greenhouse lettuce production at the time of author's visit and consequently, the village secured its position within the top deciles of high-income-earning villages from sales of the local products until today (Statistics Korea, Agriculture, Forestry, and Fishery Survey 2009. Available from http://kostat.go.kr/portal/ eng/pressReleases/2/4/index.board?bmode=read\&bSeq=\&aSeq=272271\&pageNo=1\&rowNum= 10\&navCount=10\&currPg=\&sTarget=title\&sTxt= (accessed 26 February 2016).

6 This section is derived in part from an article published in Development in Practice, reprinted by permission of the publisher (copyright Taylor \& Francis Ltd, www.tandfonline.com). Available from: http:// dx.doi.org/10.1080/09614524.2016.1210086 (see Yang, 2016a).
} 
also because LW lacked the capacity to act as an implementing organization for a participatory approach, as the interviewees admitted. The interviewees argued, however, that the failure of Project A taught them many things, and that, as a result of the learning from this failure, along with different external factors, such as a more flexible donor organization sponsoring their activities, they were seeing "changes", albeit slow, and were expecting a more positive outcome from Project B.

\section{Pre-planning rarely implemented with a participatory approach}

Pre-planning based on a participatory approach is a critical factor that can lead to the successful implementation of any project. Early in the research, however, it became obvious that one of the main problems faced by LW during the implementation of Project A was the low level of interest of local people in the project's activities. The interviews and the review of the project documents suggest that the lack of a needs assessment involving villagers' participation may have derailed Project A from the start. The general manager of the Siem Reap office mentioned that "villagers were only interested in either agriculture or profit-making projects. No interest in education."

This appears to be one of the limitations of "doing business as usual" - one of the activities of LW was to focus on the care and education of children. Not only was the target population not decided upon based on prior consultation with the targeted village, but the education curriculum was also initiated by LW with no rigourous needs assessment or villagers' involvement. While the general manager made the excuse that he had been in contact with village people ever since LW had been stationed in Siem Reap, the local office never received proper training on how to undertake a needs assessment or conduct participatory processes. In addition, it was never specified who were to be categorized as "vulnerable people" under the Education for Vulnerable People in Siem Reap project. The stated purpose of the project makes clear that the main target should be "women", but at the same time emphasizes the needs to educate vulnerable "children". At the actual implementation, every adult aged between 15 and 45 years, as well as children of primary school ages, were to participate and benefit from the programme. In summary, LW appears to have acted as an executor, considering the village as a "subject" or "recipient" to help and a "target" to change, rather than as a "partner" to work with.

Why did all these wrong steps happen? Could this have been avoided? If not, how can this be prevented in the future? The discussion in the section below makes an attempt to find answers to these questions. An argument is made that what matters the most is, as demonstrated in case study I above, the ownership and genuine participation of local people. 


\section{Perception of values: intrinsic or external?}

We not only studied [read books], it [what we learned from classes] was also practical. (A resident-participant replying to the open-ended question "Have there been any changes in your life since the programme?" in an assessment questionnaire.)

In an assessment survey for Project A with a selected sample of 30 persons out of 132 adult participants, about one third of the respondents termed the programme "unsatisfactory". The quotation above makes clear what the residents in fact wanted - that is, something that would be "practical". The class that received the highest satisfaction rate was agriculture, while literacy and language courses did not appear to attract participants. In terms of participation in the programme, LW admitted that it was hard to induce a high participation rate among adult residents, particularly at the beginning. The initial number of participants targeted was 320 (80 from each town and village for the first and second half periods), but the actual registration was 213 persons (about 67 per cent of the target) and the participation rate from the village was very low, with only 21 participants for the first period. Dissatisfaction was even greater with the Khmer class, which recorded the lowest participation rate.

Why did this happen? The main reason is because from the pre-planning stage, village (and town) residents were not considered as a main "partner" with whom the content of the offered programme should be discussed. The general manager admitted that to start with he wanted to focus on one village for the project but by consulting with the director of education department of the district, and not with the village people themselves, about which types of education programmes might be helpful for the region, the target area had expanded to cover a town in addition to a village within the district (obviously, the director would have wanted the programme to produce visible effects, rather than the limited and probably unnoticeable effects from a small village). The completion rate was even worse for the first half period, with only about 29 per cent of the 213 registered participants completing (attendance of 70 per cent or above for the period). Only by the second half period did the participation among rural people increase (from 26.3 per cent to 35 per cent), ${ }^{7}$ and the completion rate reached 100 per cent.

Then, how did this later improvement occur? A couple of explanations can be offered. The classes were originally planned every day for three hours, regardless of the season and farming schedule. Participation during the dry and busy season (in the

\footnotetext{
7 Meanwhile, the number of female participants in the town dropped from 65 to 43 . To understand this phenomenon requires further in-depth study involving a survey or an interview with women in the town. This, however, does not affect the overall findings and conclusion of the study.
} 
first half period) was low, which is not surprising when one takes the agricultural context into consideration. Then in the second half period, LW came up with various incentives and support mechanisms to boost the participation rate. First, there was encouragement from the Buddhist temple in the region. ${ }^{8}$ The participation rate noticeably increased from the upper 60 s to above 90 per cent, after a meeting with people at a temple led by a head monk in the region. Second, organized transportation support was provided during the rainy season and a practical livestock model regarding how to raise piglets attracted participants. This illustrates that the programme was beginning to respond to local people's concerns.

From this, it can be interpreted that residents and potential participants had not seen the programme as something meaningful and helpful for their life but rather as something that had been initiated and imposed by an external NGO from one of many donor countries present in the region. In addition, only after the monk's preaching about and his official support for the programme, ${ }^{9}$ and their participation in it, they came to the conclusion that the project could help their real everyday life, did residentparticipants begin to recognize it as their own. Thus, participation finally began to rise in the second half period.

The general manager of the LW Siem Reap office repeated that LW needed "time" to build trust, and constant "little jabs" to "bring" about changes, but that a participatory approach would perhaps involve getting to know and cater to village people's "wants" (intrinsic values), not what external donors want to "bring" (external values). Indeed, the general manager was of the understanding that the success of a community development project requires "people participation" and this, in turn, requires a "long-term relationship" that allows trust and empathy to be built between the involved parties. While he said "time", this can be read as "ownership".

For Project B, LW decided to focus on one village only and to more actively engage the villagers by using the existing VDC headed by the village chief and consisting of 14 other Krom (commune) chiefs. While the monitoring report of Project B highlighted "villagers' low participation"10 in every key adult literacy and income generation project, and thus did not offer a much brighter picture than that for Project $A$, unofficial assessments in the field (from interviews) were rather positive.

\footnotetext{
8 Almost 97 per cent of the population of Cambodia is Buddhist and Buddhist monks are highly respected in the region.

9 This invites us to consider the usefulness of involving local leadership and offering capacity-building training, if necessary, at the beginning of any project with a participatory approach.

10 The annual participation rate for literacy classes was as low as 53 per cent and agricultural training was delivered late due to low participation - even later on only 17 persons participated while livestock training was cancelled completely (LotusWorld, 2014).
} 
Although slowly, subtle changes were being witnessed and, chances for success were being sensed - for instance, local people would voluntarily report where maintenance repairs were required, whereas earlier no one would care or at least report it. People would stay longer during VDC meetings and the like, and would request nothing in return for their participation.

At the centre of these positive assessments, LW perceived that the village had begun to trust and cooperate with the external NGO. It is worth noting, however, that the approach of LW to the project and the village also changed, which may have contributed to the increase in collaboration. For example, LW waited for VDC to decide what the self-help work would produce. At the time of the interviews, LW was planning to host a contest in the village in which the best suggestion would win a prize, as a way of increasing participation and ownership. Although it is not clear who would decide the winner, this demonstrates a shift in the vision of LW.

Unless villagers participate, we're not going to decide what to produce. It's because it shouldn't be decided by us. It should be done what they [villagers] can and want to make... [The contest] should give a lot on their mind. They will think 'what can we do?', 'we're going to try this or that way', and the like. (Interview with general manager of the LW Siem Reap office, emphasis in original)

This quotation contrasts with the earlier perception with regard to the role of the village. The quote given below indicates that ownership of the programme for Project A was to be with LW, not with the village and people.

There is a village committee, yes. We had thought about using it but, for our concept, for the education programme we were to offer, the existing committee was not going to be of any help. And they did not want it, either. ...Their interests were more about agriculture or making profits. No interest in education [literacy and languages] and, indeed, no active participation when we asked. (Interview with general manager, emphasis added)

At the beginning of Project $A$, the concept of LW towards education was considered more important than the villagers' needs and interest and, thus, its understanding of the needs of literacy education outweighed the villagers' need for agricultural training and training in other areas. However, in Project B, LW works with the existing VDC and is much more open to local people's choices, and as a result, is seeing more potential in terms of positive outcomes and, probably, sustainable impacts. 


\section{SYNTHESIS OF THE FINDINGS}

"Learning from the previous failure [of Project A]", both the general manager and the staff interviewed at the LW Project B field location in the second case study expressed their confidence in changes that were observed. They said that the changes were being felt as a result of the "improved attitudes" of village people. To the researcher, however, the changes were mainly due to a different approach by LW in its encounters with village people. This goes back to what is meant by "participation".

Participation as freedom is not only the right to participate effectively in a given space, but the right to define and to shape that space. ...we must explore in examining the spaces for participation is to ask how they were created, and with whose interests and what terms of engagement. (Gaventa, 2006, p. 26)

If local people are invited to a "space of participation" but find that major decisions have already been made by external agents - for example, international development NGOs, such as LW - it may be the case that local people are only being invited for the purposes of co-optation, to serve external goals.

The fact that LW is attempting to disengage itself from being a main engine and executer of development projects and instead, to intentionally make room and space for the village and local people to come up with their own ideas and plans, is encouraging. This is possible only when LW views a village and local people as partners, who they can work with, rather than as beneficiaries, whom they consider require unilateral help. LW is also trying to employ more local staff so that the LW Siem Reap office will gradually be run increasingly by local people, and eventually only by local people. This, in fact, is an optimal picture of any international development cooperation effort - to help initially but eventually to ensure the village is self-reliant.

The first case study also concerned "space" for participation, as well as the internal power dynamics, of two villages classified as self-reliant (highly ranked) during the particular era of the rural community development movement in the Republic of Korea, which took place in the 1970s. It turns out that the gap in the actual performance between the two villages was mainly due to the different nature and type of village governance in each case, which was closely related to the leadership of the village and the accountability of that group. Only when people participate voluntarily and willingly, power relations can become more equitable, allowing participatory development to result in sustainable results. In summary, 
sustainable community development can be achieved when accountable leadership works with bottom-up village participation.

The results and impact can be expected to be sustained over a longer term, only "if people participate by taking initiatives independently of external institutions to change systems, ....and develop contacts with external institutions for resources and technical advice they need, but retain control over how resources are used" (Pretty, 1995 , p. 1252). Pretty (1995) describes the nature of this form of participation as being "self-mobilization". Mansuri and Rao (2012) also draw attention to the difference between "induced" and "organic" participation. Induced participation refers to participation that is promoted and stimulated by external actors, of "powerful institutions", such as governments or development agencies, while organic participation arises endogenously within a community, "by intrinsically motivated local actors", such as highly motivated leaders who successfully mobilize their local community members to take actions towards the changes. It can be argued in this study that sustainable community development is possible only through this "selfmobilizing", or "organic" community participation, while a "top-down" invitation to a "space", or "induced" participation, may bring in short-term results, but only as long as interests and support from the "top" continue, resulting in eventual failure when they stop. The key lesson from both case studies is that it is how development projects are managed - that is, whether or not they are carried out in a participatory manner, engaging the local people in any important decision-making processes - that triggers and allows genuine participation by people. Transformative power relations turn out to be a meaningful factor from both case studies.

\section{CONCLUSION}

Local participation does not work when it is merely the ad hoc, myopically directed, creation of a project. It works when it has teeth, when it builds on organic movements, when it is facilitated by a responsive centre, when it is adequately and sustainably funded, and when interventions are conditioned by a culture of learning by doing. (Mansuri and Rao, 2012, pp. 23-24)

The message from the current study is clear: community participation should continue to be a core value of development cooperation efforts, particularly within the new discourse and practice of sustainability. On the one hand, the Republic of Korea could learn from its own past experiences - what works and what does not work. 
Developing countries that wish to learn from the Miracle on the Han River ${ }^{11}$ should actively seek, and also be selective on, what is worth learning and what is not. On the other hand, the Republic of Korea, as an emerging donor country, which is sending an increasing number of NGOs to work with various development partners, should also pay more attention to the way those NGOs work in and with local communities.

11 It refers to the rapid economic growth in Republic of Korea, which was achieved within just a few decades in the late twentieth century. Han is the name of the river which runs across Seoul, the capital city. 


\section{REFERENCES}

Amsden, Alice. H., and Alisa DiCaprio (2012). Understanding the dynamics of elite behavior in a development context. In The Role of Elites in Economic Development, Alice H. Amsden, Alisa DiCaprio, and James A. Robinson, eds. Oxford: Oxford University Press.

Arnstein, Sherry R. (1969). A ladder of citizen's participation. Journal of American Institute of Planners, vol. 35, No. 4, pp. 216-224.

Bhatnagar, Bhuvan, and Aubrey C. Williams (1992). Participatory development and the World Bank: potential directions for change. Discussion Papers, No. 183. Washington, D.C.: World Bank.

Chambers, Robert (2005). Ideas for Development. London: Routledge.

Choguill, Marisa B. Guaraldo (1996). A ladder of community participation for underdeveloped countries. Habitat International, vol. 20, No. 3, pp. 431-444.

Cleaver, Frances (2001). Institutions, agency and the limitations of participatory approaches to development. In Participation: The New Tyranny? Bill Cooke and Uma Kothari, eds. London and New York: Zed Books.

Cooke, Bill, and Uma Kothari, eds. (2001). Participation: The New Tyranny? London and New York: Zed Books.

Cornwall, Andrea (2004). Spaces for transformation? Reflections on issues of power and difference in participation in development. In Participation from Tyranny to Transformation? Exploring New Approaches to Participation in Development, Samuel Hickey and Giles Mohan, eds. London and New York: Zed Books.

Cornwall, Andrea, ed. (2011). The Participation Reader. London and New York: Zed Books.

Cornwall, Andrea, and Karen Brock (2005). What do buzzwords do for development policy? A critical look at 'participation', 'empowerment' and 'poverty reduction'. Third World Quarterly, vol. 26, No. 7, pp. 1043-1060.

Dasgupta, Aniruddha, and Victoria A. Beard (2007). Community driven development, collective action and elite capture in Indonesia. Development and Change, vol. 38, No. 2, pp. 229-249.

DiCaprio, Alisa (2012). Introduction: the role of elites in economic development. In The Role of Elites in Economic Development, Alice H. Amsden, Alisa DiCaprio and James A. Robinson, eds. Oxford: Oxford University Press.

Fritzen, Scott A. (2007). Can the design of community-driven development reduce the risk of elite capture? Evidence from Indonesia. World Development, vol. 35, No. 8, pp. 1359-1375.

Gaventa, John (2004). Towards participatory governance: assessing the transformative possibilities. In Participation from Tyranny to Transformation? Exploring New Approaches to Participation in Development, Samuel Hickey and Giles Mohan, eds. London and New York: Zed Books.

(2006). Finding the spaces for change: a power analysis. IDS Bulletin, vol. 37, No. 6, pp. 23-33.

Han, D. (2010). Life world of village leaders during the Saemaul movement in the 1970s: focusing on male leaders. Society and History, vol. 88, pp. 267-305 (In Korean).

Han, Seung-Mi (2004). The new community movement: Park Chung Hee and the making of state populism in Korea. Pacific Affairs, vol. 77, No. 1, pp. 69-93. 
Hickey, Samuel, and Giles Mohan, eds. (2004). Participation from Tyranny to Transformation? Exploring New Approaches to Participation in Development. London and New York: Zed Books.

Hildyard, Nicholas, and others (2001). Pluralism, participation and power: joint forest management in India. In Participation: The New Tyranny? Bill Cooke and Uma Kothari, eds. London and New York: Zed Books.

Hwang, B. (2011). The change of agricultural production process and peasants appropriation of state through the Saemaul Undong in 1970s. Society and History, vol. 90, pp. 5-48 (In Korean).

Hwang, Y. (2006). Reappraisal of rural Saemaul Undong. Agricultural History Studies, vol. 5, No. 2, pp. 17-53 (In Korean).

Kelly, Ute (2004). Confrontations with power: moving beyond 'the tyranny of safety' in participation. In Participation from Tyranny to Transformation? Exploring New Approaches to Participation in Development, Samuel Hickey and Giles Mohan, eds. London and New York: Zed Books.

Kim, Ho-Jin (1981). A study on grassroot leadership profiles in Korea. Journal of East and West Studies, vol. 10, No. 2, pp. 1-22.

Kim, Y. (2009). Their Saemaul Undong. Seoul: Poorunyuksa (In Korean).

Kothari, Uma (2001). Power, knowledge and social control in participatory development. In Participation: The New Tyranny? Bill Cooke and Uma Kothari, eds. London and New York: Zed Books.

Lee, H. (2013). A study on the importance of the village leader in local development: on the case of Saemaul Undong in the 1970s. Korean Journal of Public Administration, vol. 51, No. 1, pp. 207-236 (In Korean).

LotusWorld (2013). A report of the education support project for vulnerable people in Siem Reap, Cambodia in 2012. Cambodia (In Korean).

(2014). A report of the 2013 the 'Village B' Project - the $2^{\text {nd }}$ stage. Internal document (In Korean).

Lyons, Michael, Carin Smuts, and Anthea Stephens (2001). Participation, empowerment and sustainability: (How) do the links work? Urban Studies, vol. 38, No. 8, pp. 1233-1251.

Mansuri, G., and Vijayendra Rao (2004). Community-based and driven development: a critical review. Policy Research Working Paper, No. 3209. Washington, D.C.: World Bank.

(2012). Can participation be induced? Some evidence from developing countries. Policy Research Working Paper, No. 6239. Washington, D.C.: World Bank.

Mohan, Giles, and Kristian Stokke (2000). Participatory development and empowerment: the dangers of localism. Third World Quarterly, vol. 21, No. 2, pp. 247-268.

Moore, Mick (1985). Mobilization and disillusion in rural Korea: the Saemaul movement in retrospect. Pacific Affairs, vol. 57, No. 4, pp. 577-598.

Mosse, David (2001). 'People's knowledge', participation and patronage: operations and representations in rural development. In Participation: The New Tyranny? Bill Cooke and Uma Kothari, eds. London and New York: Zed Books.

Park, D. (1974). Roles, selection and guidance of Saemaul leaders. Korean Journal of Public Administration, vol. 12, No. 2, pp. 48-82 (In Korean). 
Park, Jin-Hwan (1998). The Saemaul Movement: Korea's Approach to Rural Modernization in 1970s. Seoul: Korea Rural Economics Institute.

Platteau, Jean-Philippe (2004). Monitoring elite capture in community-driven development. Development and Change, vol. 35, No. 2, pp. 223-246.

Platteau, Jean-Philippe, and Anita Abraham (2002). Participatory development in the process of endogenous community imperfections. Journal of Development Studies, vol. 39, No. 2, pp. 104-136.

Pretty, Jules N. (1995). Participatory learning for sustainable agriculture. World Development, vol. 23, No. 8 , pp. 1247-1263.

Rahman, Muhammad Anisur (1995). Participatory development: towards liberation or co-optation? In Community Empowerment: A Reader in Participation and Development, Gary Craig and Marjorie Mayo, eds. London and New York: Zed Books.

Republic of Korea, Ministry of Home Affairs (MOHA) (1980). Ten Year's History of Saemaul Undong. Seoul (In Korean).

VeneKlasen, L., and V. Miller (2002). A New Weave of Power, People and Politics: The Action Guide for Advocacy and Citizen Participation. Oklahoma: World Neighbours.

Whang, In-Joung (1981). Impact of the Saemaul Undong on rural development in Korea. Journal of East and West Studies, vol. 10, No. 1, pp. 23-41.

Wilcox, David (1994). The Guide to Effective Participation. Brighton, United Kingdom: Partnership.

Williams, Glyn (2004). Towards a repoliticization of participatory development: political capabilities and spaces of empowerment. In Participation from Tyranny to Transformation? Exploring New Approaches to Participation in Development, Samuel Hickey and Giles Mohan, eds. London and New York: Zed Books.

Wong, Sam (2012). Tackling elite capture by the 'counter-elite' and 'co-opt-elite' approaches in Bangladesh and Ghana. In The Role of Elites in Economic Development, Alice H. Amsden, Alisa Dicaprio and James A. Robinson, eds. Oxford: Oxford University Press.

Yang, Yunjeong (2015). Saemaul Undong revisited: a case of state-society dynamics in social capital mobilisation, focusing on the role of local leaders in South Korea of the 1970s. Journal of International Development. Published online 10 August 2015.

(2016a). Commitments and challenges in participatory development: a Korean NGO working in Cambodia. Development in Practice, vol. 26, No. 7, pp. 853-864.

(2016b). Community participation for sustainable rural development: revisiting South Korean rural modernization of the 1970s. Community Development Journal. Available from http://cdj.oxfordjournals.org/content/early/2016/07/11/cdj.bsw023.abstract.

Yoon, C. (2011). The Saemaul movement in the 1970s seen by oral testimonies: in-between the building and becoming its leaders. Society and History, vol. 90, pp. 79-109 (In Korean). 


\section{APPENDIX I}

\section{Summary of the villages and interviewees (case study I)}

\begin{tabular}{|c|c|c|}
\hline & Village A & Village B \\
\hline \multirow[t]{2}{*}{ Size } & 46 households, 284 persons (1973) & 80 households, 504 persons (1970) \\
\hline & 46 households, 276 persons (1977) & 89 households, 505 persons (1976) \\
\hline $\begin{array}{l}\text { Year classified as } \\
\text { a "self-reliant" village }\end{array}$ & 1973 & 1977 \\
\hline $\begin{array}{l}\text { Saemaul } \\
\text { income-earning } \\
\text { projects }\end{array}$ & $\begin{array}{l}\text { Forest nurseries, pig farming (1973) } \\
\text { Cow farming (1977) } \\
\text { Ginseng production (1978-1979) }\end{array}$ & $\begin{array}{l}\text { Greenhouse lettuce production } \\
\text { (since 1968) }\end{array}$ \\
\hline How it started & $\begin{array}{l}\text { Pinpointed as a "showcase } \\
\text { Saemaul village" by the } \\
\text { then-head of province, who was } \\
\text { impressed by its unique } \\
\text { appearance of mostly tiled-roof } \\
\text { houses }\end{array}$ & $\begin{array}{l}\text { A young missionary's rural } \\
\text { enlightenment movement in } \\
\text { collaboration with the village's } \\
\text { young folks to save and to grow } \\
\text { greenhouse lettuce to make } \\
\text { extra income during winter }\end{array}$ \\
\hline $\begin{array}{l}\text { Village chief } \\
\text { (Rijang) and/or } \\
\text { Saemaul Undong } \\
\text { leader }\end{array}$ & Kim J. (aged late 30s in late 1960s) & Jeon (aged 27 years in 1973) \\
\hline $\begin{array}{l}\text { Leadership } \\
\text { accountability } \\
\text { and nature }\end{array}$ & $\begin{array}{l}\text { Son of earlier village chief; } \\
\text { collected VDC members himself; } \\
\text { quasi-dictatorial }\end{array}$ & $\begin{array}{l}\text { Son of an immigrant family } \\
\text { (grandfather having been chief of } \\
\text { another village); elected by majority } \\
\text { vote at a village congress after } \\
\text { having worked as assistant chief } \\
\text { of one of } 5 \text { village subgroups for } \\
4 \text { years; worked along with other } \\
\text { elected VDC members }\end{array}$ \\
\hline $\begin{array}{l}\text { Earlier village } \\
\text { dynamics }\end{array}$ & $\begin{array}{l}\text { Long history of conflicts between } \\
\text { two Kim clans (the leader being } \\
\text { a member of the two clans) }\end{array}$ & $\begin{array}{l}\text { Strong self-help focus, initiated } \\
\text { and supported by an external } \\
\text { missionary, participatory }\end{array}$ \\
\hline $\begin{array}{l}\text { Current villagers' } \\
\text { evaluation }\end{array}$ & $\begin{array}{l}\text { Failure: "no income, but only } \\
\text { performances" }\end{array}$ & $\begin{array}{l}\text { Achieved the self-made slogan } \\
\text { of "high-income village" }\end{array}$ \\
\hline $\begin{array}{l}\text { Interviewees } \\
\text { (age in 1972) }\end{array}$ & $\begin{array}{l}\text { Kim, a (40), Rijang in the mid-1970s } \\
\text { Kim, b (35), assistant chief } \\
\text { throughout 1970s } \\
\text { Jeong (43), Rijang in the late 1970s } \\
\text { Cho (19), incumbent Rijang }\end{array}$ & $\begin{array}{l}\text { Jeon (26), former Samaeul Leader } \\
\text { and incumbent Rijang } \\
\text { Min (31), Founding President of } \\
\text { Village B's Credit Union }\end{array}$ \\
\hline
\end{tabular}




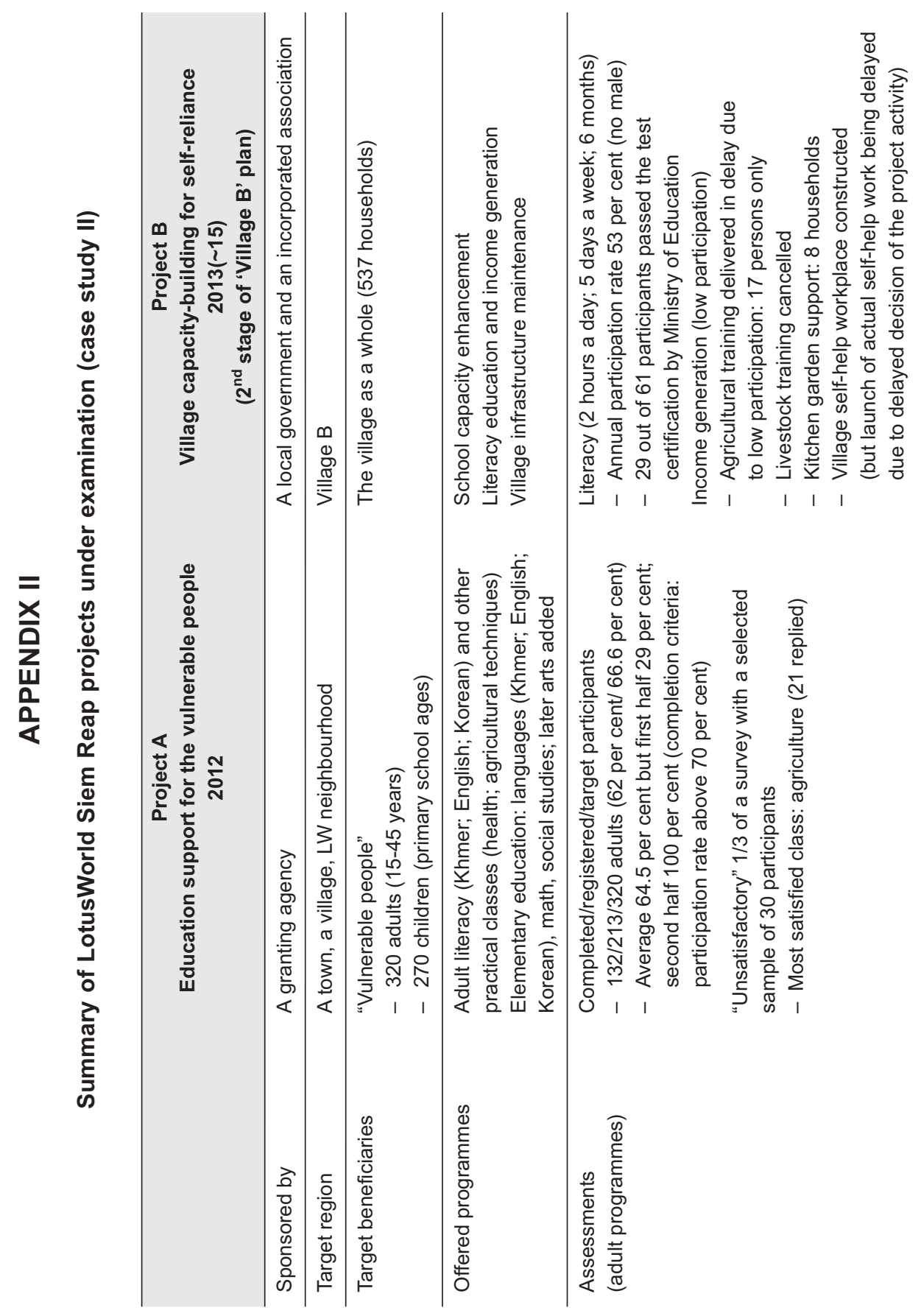




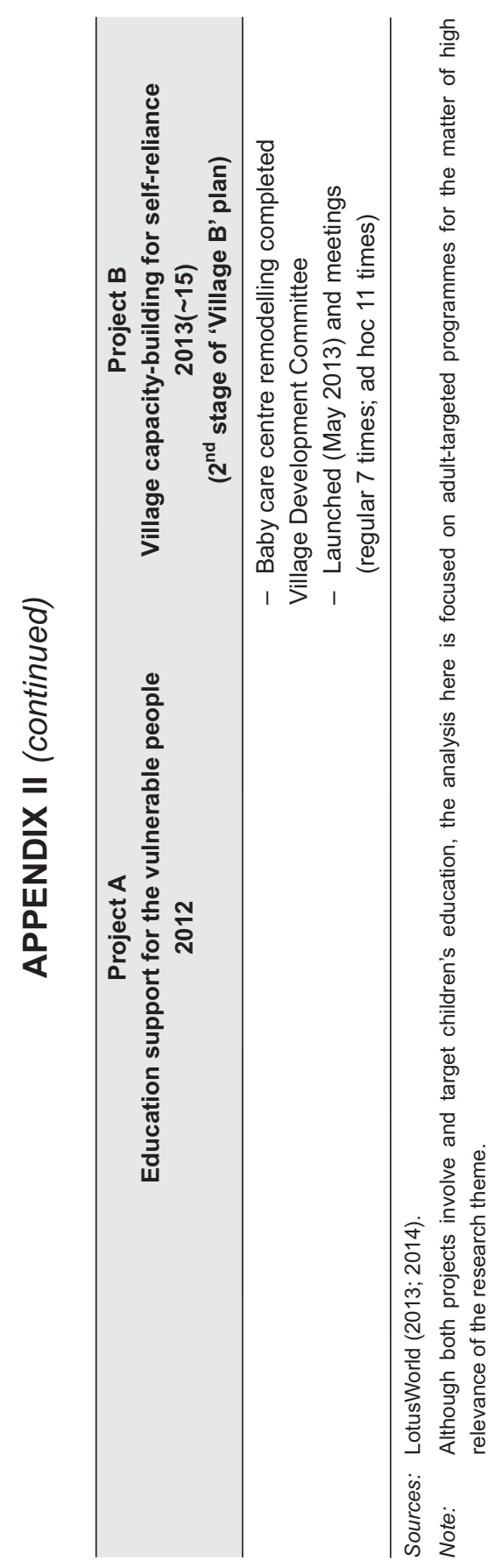

